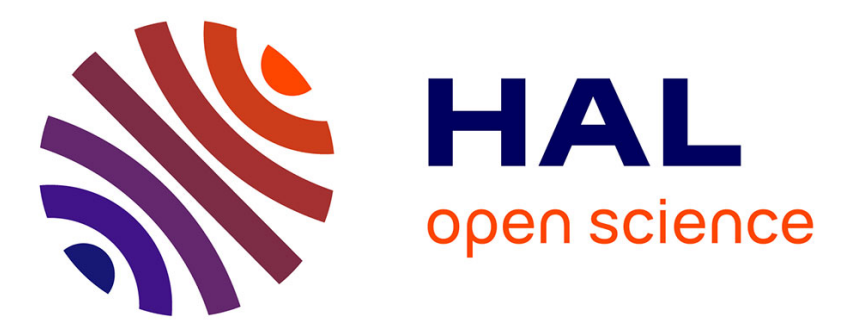

\title{
One-step synthesis of few-layered-graphene/alumina powders for strong and tough composites with high electrical conductivity
}

Alicia Weibel, Andréas Flaureau, Adeline Pham, Geoffroy Chevallier, Jérôme Esvan, Claude Estournès, Christophe Laurent

\section{To cite this version:}

Alicia Weibel, Andréas Flaureau, Adeline Pham, Geoffroy Chevallier, Jérôme Esvan, et al.. Onestep synthesis of few-layered-graphene/alumina powders for strong and tough composites with high electrical conductivity. Journal of the European Ceramic Society, 2020, 40 (15), pp.5779-5789. 10.1016/j.jeurceramsoc.2020.06.029 . hal-03031659

\section{HAL Id: hal-03031659 https://hal.science/hal-03031659}

Submitted on 30 Nov 2020

HAL is a multi-disciplinary open access archive for the deposit and dissemination of scientific research documents, whether they are published or not. The documents may come from teaching and research institutions in France or abroad, or from public or private research centers.
L'archive ouverte pluridisciplinaire HAL, est destinée au dépôt et à la diffusion de documents scientifiques de niveau recherche, publiés ou non, émanant des établissements d'enseignement et de recherche français ou étrangers, des laboratoires publics ou privés. 


\section{OATAO \\ Open Archive Toulouse Archive Ouverte}

\section{Open Archive Toulouse Archive Ouverte (OATAO)}

OATAO is an open access repository that collects the work of Toulouse researchers and makes it freely available over the web where possible

This is an author's version published in: http://oatao.univ-toulouse.fr/26620

Official URL: https://doi.org/10.1016/j.jeurceramsoc.2020.06.029

To cite this version: Weibel, Alicia and Flaureau, Andréas and Pham, Adeline and Chevallier, Geoffroy and Esvan, Jérôme and Estournès, Claude and Laurent, Christophe One-step synthesis of few-layered-graphene/alumina powders for strong and tough composites with high electrical conductivity. (2020) Journal of the European Ceramic Society, 40 (15). 5779-5789. ISSN 09552219

Any correspondence concerning this service should be sent to the repository administrator: tech-oatao@listes-diff.inp-toulouse.fr 
Original Article

\title{
One-step synthesis of few-layered-graphene/alumina powders for strong and tough composites with high electrical conductivity
}

\author{
Alicia Weibel $^{\mathrm{a}}$, Andréas Flaureau ${ }^{\mathrm{a}}$, Adeline Pham ${ }^{\mathrm{a}, 1}$, Geoffroy Chevallier $^{\mathrm{a}, \mathrm{b}}$, Jérôme Esvan ${ }^{\mathrm{c}}$, \\ Claude Estournès ${ }^{\mathrm{a}}$, Christophe Laurent ${ }^{\mathrm{a}, \mathrm{H}}$ \\ ${ }^{a}$ CIRIMAT, CNRS-INP-UPS, Université Toulouse 3 Paul-Sabatier, 118 route de Narbonne, F-31062, Toulouse Cedex 9, France \\ ${ }^{\mathrm{b}}$ Plateforme Nationale CNRS de Frittage Flash, PNF ${ }^{2}$, MHT, Université Toulouse 3 - Paul-Sabatier, 118 route de Narbonne, F-31062, Toulouse Cedex 9, France \\ ${ }^{\mathrm{c}}$ CIRIMAT, CNRS-INP-UPS, INP-ENSIACET, 4 allée Emile Monso, BP 44362, F-31030, Toulouse Cedex 4, France
}

\section{A R T I C L E I N F O}

Keywords:

Few-layered-graphene

Alumina

CVD

Nanocomposites

Mechanical and electrical properties

\begin{abstract}
A B S T R A C T
The chemical vapor deposition of carbon onto a commercial $\alpha-\mathrm{Al}_{2} \mathrm{O}_{3}$ powder bed produces a pristine film of fewlayered-graphene (FLG) uniformly covering the $\alpha-\mathrm{Al}_{2} \mathrm{O}_{3}$ grains. This obviates both the manipulation of nanocarbons, lengthy mixing steps and the risk of damaging any pre-existing graphene platelets. The powders are consolidated to $99 \%$ by SPS, producing samples where a FLG film is located along the grain boundaries of the submicron $\alpha-\mathrm{Al}_{2} \mathrm{O}_{3}$. Compared to the pure $\alpha-\mathrm{Al}_{2} \mathrm{O}_{3}$, the composites are moderately stronger and similarly tough and hard due to crack-deflection and crack-bridging and they are electrically conducting with a percolation threshold below 0.74 vol.\% of carbon. The high conductivity values reflect the high quality of the thin FLG film and its continuous nature over very long distances. The samples are characterized by Raman spectroscopy, X-ray photoelectron spectroscopy, scanning and transmission electron microscopy.
\end{abstract}

\section{Introduction}

Graphene/ceramic composites [1-4], notably $\mathrm{Al}_{2} \mathrm{O}_{3}$-matrix samples, have very attractive thermal [5], electrical [6-9], mechanical [8-17] and tribological [17] properties. Carbon is present in these samples as discrete particles of few-layered-graphene (FLG) platelets with 2-10 layers or in the form of thicker stacks (up to about $100 \mathrm{~nm}$ ). Such platelets are denoted variously as graphene-nanosheets (GNS), -nano-platelets (GNP), -platelets (GPL) or graphite platelets. The composites are usually prepared by sintering graphene $/ \mathrm{Al}_{2} \mathrm{O}_{3}$ powders and the prior preparation of the powders is indeed regarded as the key step in the process. The reported methods, such as the salt precursor method, colloidal processing and molecular mixing, involve many successive steps. Most importantly they share the use of pre-existing graphene agglomerates prepared by chemical [18] or mechanical exfoliation [19] of graphite. These are lengthy routes prone to introducing contamination and/or undesirable structural defects, as in graphene oxide or reduced graphene oxide. An alternative method has been reported, using the chemical vapour deposition (CVD) of a carbon-containing gas for the formation of graphene films on porous $\mathrm{Al}_{2} \mathrm{O}_{3}$ ceramic substrates [20], foams [21] and powders [22-24]. Rümmeli et al. [22] have reported the encapsulation of the oxide $\left(\mathrm{Al}_{2} \mathrm{O}_{3}, \mathrm{MgO}, \mathrm{SiO}_{2}\right.$ and
$\mathrm{Ga}_{2} \mathrm{O}_{3}$ ) grains by $1-8$ graphitic layers. Our group has recently reported the formation of FLG/MgO powders by the decomposition of methane on an $\mathrm{MgO}$ powder bed. Moreover, the so-obtained powders have been consolidated by spark plasma sintering (SPS), producing strong, hard and electrically conducting FLG/MgO composites [23]. Here, we propose to extend this one-step fast route, which does not involve any mixing, to the synthesis of $\mathrm{FLG} / \mathrm{Al}_{2} \mathrm{O}_{3}$ powders, to consolidate the soobtained powders by SPS and to investigate the microstructure and the mechanical and electrical properties of the so-obtained fully dense composite samples. Such a study on $\mathrm{FLG} / \mathrm{Al}_{2} \mathrm{O}_{3}$ samples was reported very recently [24], building also on our previous work on FLG/MgO [23]. There are several differences between the present study and [24], including a study of the powders by X-ray photoelectron spectroscopy and a report that the strength of the sintered composites is increased, not decreased, by the presence of moderate amounts of FLG. We also bring to light some reinforcement mechanisms including crack-deflection, crack-bridging and the debonding of the FLG film bridging two grains.

\footnotetext{
* Corresponding author.

E-mail address: laurent@chimie.ups-tlse.fr (C. Laurent).

${ }^{1}$ Present address: LPCNO, Université de Toulouse, CNRS, UPS, INSA, 135 Avenue de Rangueil, F-31077 Toulouse cedex 4, France.
} 
Table 1

CVD atmosphere $\left(\mathrm{CH}_{4} / \mathrm{Ar}\right)$ and characteristics of the powders: carbon content $\left(\mathrm{C}_{\mathrm{n}}\right.$ and $\mathrm{C}_{\mathrm{v}}$ ), Raman $\mathrm{I}_{\mathrm{D}} / \mathrm{I}_{\mathrm{G}}$ and $\mathrm{I}_{2 \mathrm{D}} / \mathrm{I}_{\mathrm{G}}$ ratios for the powders and dense samples. nm: not measurable.

$\begin{array}{llllllll}\text { Sample } & \begin{array}{l}\mathrm{CH}_{4} / \mathrm{Ar} \\ \mathrm{L} / \mathrm{h} / \mathrm{L} / \mathrm{h}\end{array} & \begin{array}{l}\mathrm{C}_{\mathrm{n}} \\ \text { wt.\% }\end{array} & \begin{array}{l}\mathrm{C}_{\mathrm{v}} \\ \text { vol.\% }\end{array} & \begin{array}{l}\mathrm{I}_{\mathrm{D}} / \mathrm{I}_{\mathrm{G}} \\ \text { powders }\end{array} & \begin{array}{l}\mathrm{I}_{2 \mathrm{D}} / \mathrm{I}_{\mathrm{G}} \\ \text { powders }\end{array} & \begin{array}{l}\mathrm{I}_{\mathrm{D}} / \mathrm{I}_{\mathrm{G}} \\ \text { dense }\end{array} & \begin{array}{l}\mathrm{I}_{2 \mathrm{D}} / \mathrm{I}_{\mathrm{G}} \\ \text { dense }\end{array} \\ {\mathrm{\alpha}-\mathrm{Al}_{2} \mathrm{O}_{3}} & 0 / 0 & 0 & 0 & - & - & - & - \\ \mathrm{G} 24 & 1 / 9 & 0.13 & 0.24 & 1.72 & 1.10 & 1.74 & \mathrm{~nm} \\ \mathrm{G} 74 & 4 / 6 & 0.39 & 0.74 & 1.50 & 0.31 & 1.22 & 0.35 \\ \mathrm{G} 109 & 5 / 5 & 0.58 & 1.09 & 1.45 & 0.24 & 1.30 & 0.33 \\ \mathrm{G} 145 & 7 / 3 & 0.77 & 1.45 & 1.30 & 0.22 & 1.21 & 0.29\end{array}$

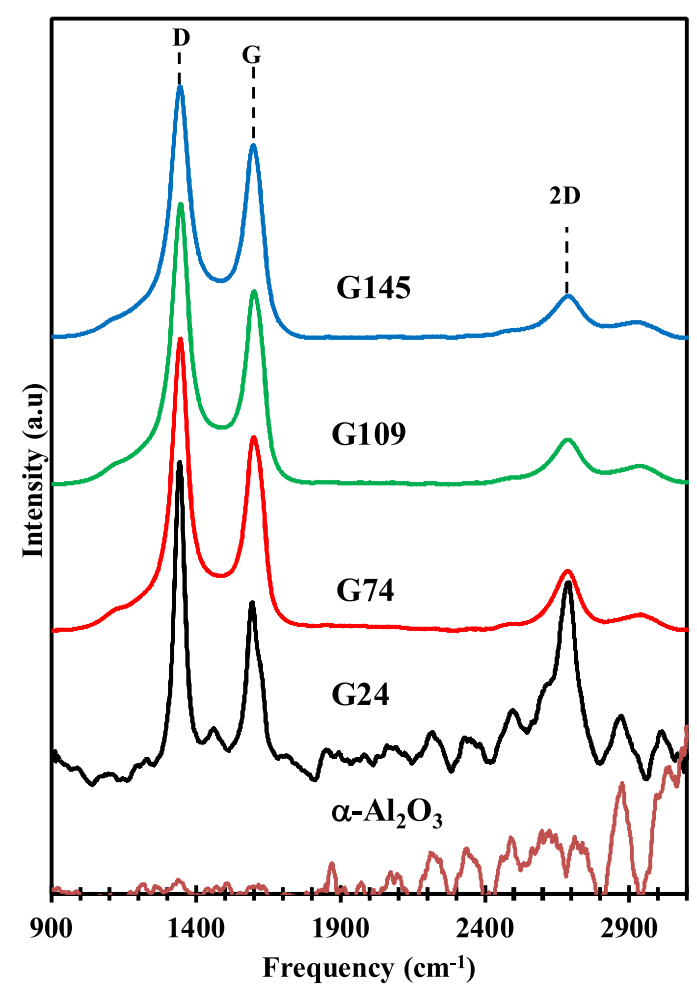

Fig. 1. Raman spectra of the $\alpha-\mathrm{Al}_{2} \mathrm{O}_{3}$ and $\mathrm{FLG} / \mathrm{Al}_{2} \mathrm{O}_{3}$ powders (G24, G74, G109 and G145). The spectra of G74, G109 and G145 are normalized with the G band at $100 \%$. The dashed lines are guides to the eye.

\section{Experimental methods}

\subsection{Raw materials}

A commercial $\alpha-\mathrm{Al}_{2} \mathrm{O}_{3}$ powder (Baikowski BMA 15, > $99.9 \%$, $284 \pm 112 \mathrm{~nm}$ ) was divided into five batches. Four of them were submitted to a chemical vapor deposition (CVD) treatment performed in order to decompose methane $\left(\mathrm{CH}_{4}\right)$ and deposit carbon onto the $\alpha$ $\mathrm{Al}_{2} \mathrm{O}_{3}$ grains. The samples $(12 \mathrm{~g})$ were heated in $\operatorname{argon}(10 \mathrm{~L} / \mathrm{h})$ up to $900{ }^{\circ} \mathrm{C}\left(15{ }^{\circ} \mathrm{C} / \mathrm{min}\right)$ and upon reaching this temperature, $\mathrm{CH}_{4}$ was introduced $(1,4,5$, and $7 \mathrm{~L} / \mathrm{h}$, respectively, while keeping the total gas flow-rate equal to $10 \mathrm{~L} / \mathrm{h}$ ). A dwell time of $75 \mathrm{~min}$ was applied at 900 ${ }^{\circ} \mathrm{C}$. Cooling down to room temperature was performed in the same $\mathrm{CH}_{4} /$ $\mathrm{Ar}$ atmosphere. The flow-rates were monitored using mass-flow controllers.

\subsection{Sintering}

The powders were consolidated by SPS (SPS632LX, Fuji electronic Industrial Co., Japan). The samples (about $3.2 \mathrm{~g}$ ) were loaded into a 20 $\mathrm{mm}$ inner-diameter graphite die. A sheet of graphitic paper was placed between the punch and the powder and between the die and the powder for easy removal. The tool was introduced in the SPS device and a uniaxial pressure of $50 \mathrm{MPa}$ was applied at room temperature in 1 min. Then, the samples were sintered in vacuum (residual cell pressure $<5 \mathrm{~Pa}$ ). A direct current with a pulse pattern of $40 \mathrm{~ms}$ on: $7 \mathrm{~ms}$ off was used. An optical pyrometer, focused on a little hole at the outer surface of the die, was used to control the temperature. A heating rate of $300{ }^{\circ} \mathrm{C} / \mathrm{min}$ was used from room temperature to $600{ }^{\circ} \mathrm{C}$. There is no temperature measurement from room temperature to $570{ }^{\circ} \mathrm{C}$. The power is automatically and gradually increased until the temperature is detected by the pyrometer at $570^{\circ} \mathrm{C}$, which takes about $2 \mathrm{~min}$. Then a 1 min dwell time is applied at $600{ }^{\circ} \mathrm{C}$ in order to offset any overshoot, which from experience is known to be very minor anyway, and stabilize the temperature of the SPS stack at $600{ }^{\circ} \mathrm{C}$ before the start of the controlled ramp. Then, the temperature was raised $\left(100{ }^{\circ} \mathrm{C} / \mathrm{min}\right)$ to $1375^{\circ} \mathrm{C}$ (only $1300{ }^{\circ} \mathrm{C}$ for pure $\alpha-\mathrm{Al}_{2} \mathrm{O}_{3}$ ), where a $5 \mathrm{~min}$ dwell was applied. A uniaxial load was gradually applied during the first heating to, and stabilization at, $600{ }^{\circ} \mathrm{C}$ and then maintained during the second heating step up to $1375{ }^{\circ} \mathrm{C}$. The corresponding pressure is equal to $100 \mathrm{MPa}$. Once the set-point of $1375{ }^{\circ} \mathrm{C}$ is reached, the pressure was increased to $150 \mathrm{MPa}$ during the first minute and maintained until the end of the dwell. A cooling rate of $100{ }^{\circ} \mathrm{C} / \mathrm{min}$ was applied down to room temperature and the uniaxial load was gradually released during the same time. The sintered specimens were in the form of pellets $20 \mathrm{~mm}$ in diameter and about $3 \mathrm{~mm}$ thick. The graphitic paper remaining on the surface was removed by polishing.

\subsection{Characterization}

The carbon content in the powders was measured by the flash combustion method with an accuracy of $\pm 2 \%$. The samples were investigated using X-ray diffraction (XRD, CuKa radiation, Bruker D4 Endeavor). Raman spectra were recorded at $532 \mathrm{~nm}$ (LabRAM 800, Horiba Jobin-Yvon) and they were averaged on three spectra. The X-ray photoelectron emission spectra were recorded using a monochromatised $\mathrm{Al} \mathrm{K} \mathrm{K}_{\alpha}(\mathrm{h} \nu=1486.6 \mathrm{eV})$ source on a Thermo Scientific KAlpha system. The X-ray spot size was about $400 \mu \mathrm{m}$. The pass energy was fixed at $30 \mathrm{eV}$ with a step of $0.1 \mathrm{eV}$ for core levels and $150 \mathrm{eV}$ for surveys (step $1 \mathrm{eV}$ ). The spectrometer energy calibration was done using the $\mathrm{Au} 4 \mathrm{f}_{7 / 2}(83.9 \pm 0.1 \mathrm{eV})$ and $\mathrm{Cu} 2 \mathrm{p}_{3 / 2}(932.8 \pm 0.1 \mathrm{eV})$ photoelectron lines. XPS spectra were recorded in direct mode $\mathrm{N}$ (Ec) and the background signal was removed using the Shirley method. The flood gun was used to neutralize charge effects on the top surface. Selected samples were observed by field-emission-gun scanning electron microscopy (FESEM, JEOL JSM 6700F and 7800F) and transmission electron microscopy (TEM, JEOL JEM 2100 F). The samples were coated with platinum (a few nanometers thick) prior to FESEM observations, in order to increase the contrasts by enhancing secondary electrons emission of carbon. For a sintered sample, a thin foil for TEM observations was prepared using a routine involving grinding with $\mathrm{SiC}$ paper, dimpling (GATAN 656) with a $1 \mu \mathrm{m}$ diamond suspension and cold ion milling at $4 \mathrm{kV}$ (GATAN PIPS 691).

The density of the specimens was measured by Archimedes' method using a hydrostatic balance (Sartorius MSE224S-YDK03) with an accuracy of $\pm 1 \%$. The relative density was calculated using $3.98 \mathrm{~g} / \mathrm{cm}^{3}$ 
G145

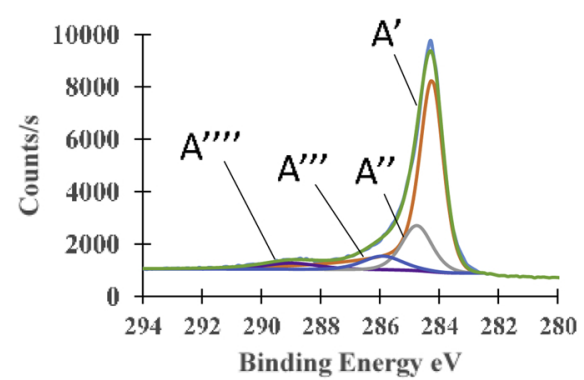

G109

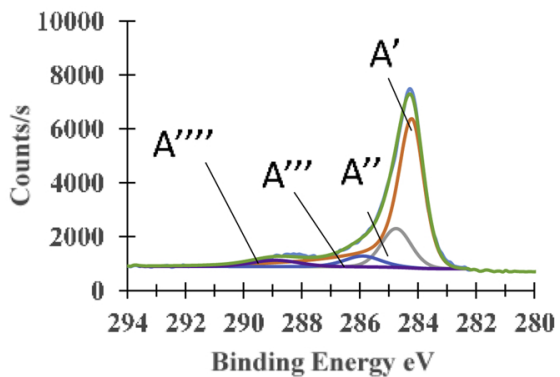

G74

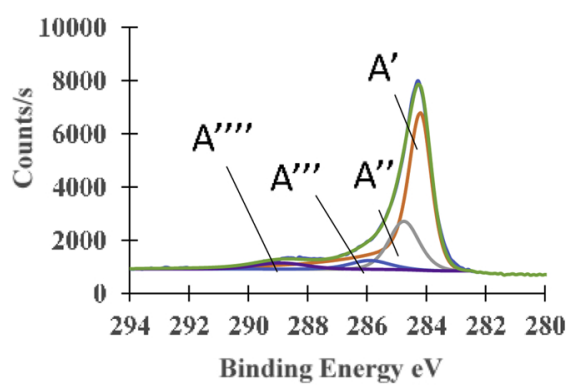

G24

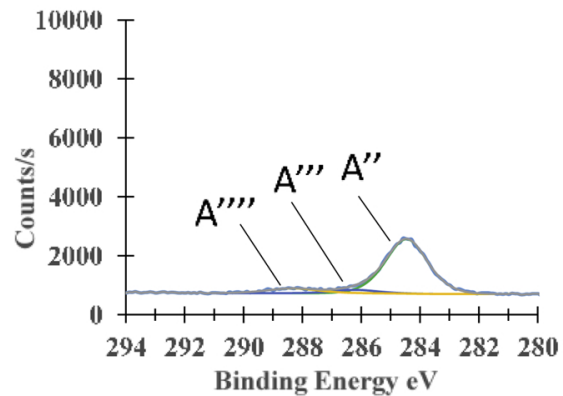

$\alpha-\mathrm{Al}_{2} \mathrm{O}_{3}$

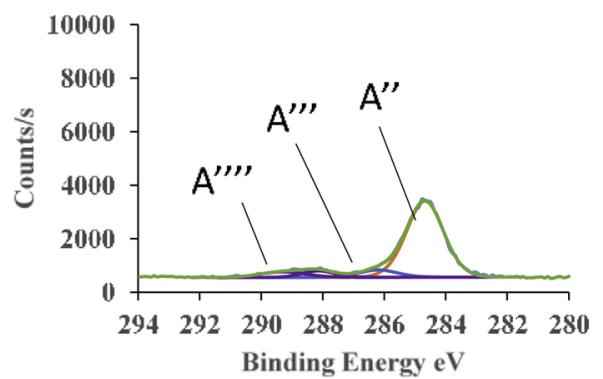

Al2p
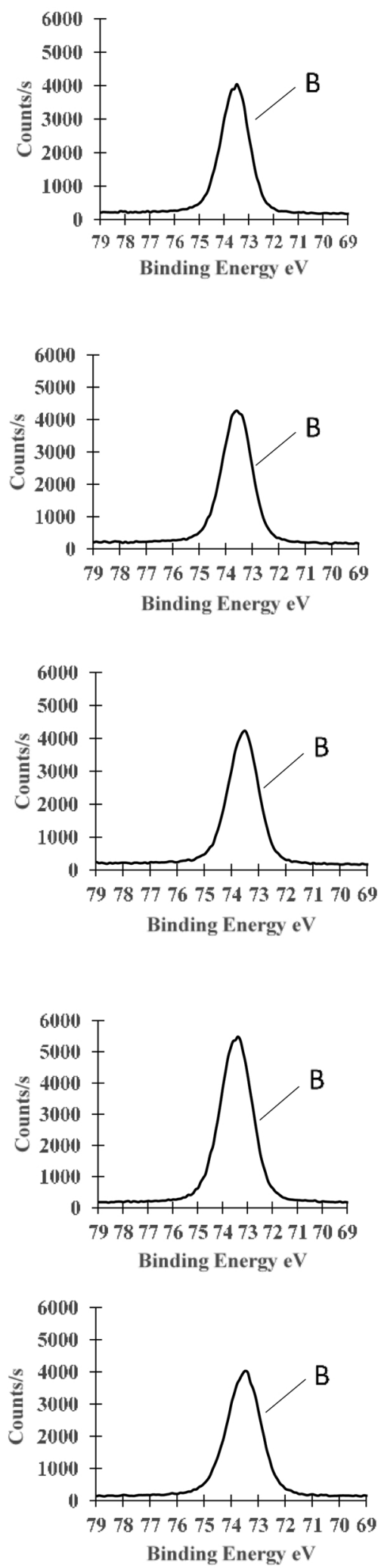

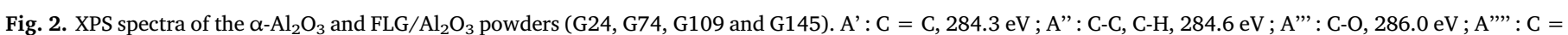
$\mathrm{O}, \mathrm{O}=\mathrm{C}-\mathrm{O}, 287$ - $290 \mathrm{eV}$; B : Al-O-Al, $73.6 \mathrm{eV}$. 
Table 2

Curve fitting results of the XPS C1s and A12p s pectra of the powders: binding energy (BE), full width at half-maximum (FWHM) and content.

\begin{tabular}{|c|c|c|c|c|}
\hline Sample & Peak & $\begin{array}{l}\mathrm{BE} \\
\mathrm{eV}\end{array}$ & $\begin{array}{l}\text { FWHM } \\
\text { eV }\end{array}$ & $\begin{array}{l}\text { Content } \\
\text { at. } \%\end{array}$ \\
\hline \multirow[t]{5}{*}{$\alpha-\mathrm{Al}_{2} \mathrm{O}_{3}$} & $\mathrm{Al} 2 \mathrm{p} \mathrm{Al}-\mathrm{OA}-\mathrm{l}$ & 73.5 & 1.4 & 31.6 \\
\hline & $\mathrm{C} 1 \mathrm{~s} \mathrm{C}=\mathrm{C}$ & - & - & - \\
\hline & $--\mathrm{CC}, \mathrm{CH}$ & 284.7 & 1.4 & 14.2 \\
\hline & $\mathrm{C}-\mathrm{O}$ & 286.2 & 1.5 & 1.4 \\
\hline & $\mathrm{C}=\mathrm{O}, \mathrm{OC}=-\mathrm{O}$ & $288.1-289.3$ & $1.3-1.7$ & $1.1-1.3$ \\
\hline \multirow[t]{5}{*}{ G24 } & $\mathrm{Al} 2 \mathrm{p} \mathrm{Al}-\mathrm{OA}-\mathrm{l}$ & 73.5 & 1.5 & 35.6 \\
\hline & $\mathrm{C} 1 \mathrm{~s} \mathrm{C}=\mathrm{C}$ & - & - & - \\
\hline & $--\mathrm{CC}, \mathrm{CH}$ & 284.5 & 1.6 & 8.8 \\
\hline & $\mathrm{C}-\mathrm{O}$ & 286.2 & 1.7 & 0.6 \\
\hline & $\mathrm{C}=\mathrm{O}, \mathrm{OC}=-\mathrm{O}$ & 288.3 & 2.0 & 0.9 \\
\hline \multirow[t]{5}{*}{ G74 } & $\mathrm{Al} 2 \mathrm{p} \mathrm{Al}-\mathrm{OA}-1$ & 73.6 & 1.3 & 26.7 \\
\hline & $\mathrm{C} 1 \mathrm{~s} \mathrm{C}=\mathrm{C}$ & 284.2 & 0.9 & 23.0 \\
\hline & $\mathrm{C}-\mathrm{C}, \mathrm{C}-\mathrm{H}$ & 284.8 & 1.2 & 7.1 \\
\hline & $\mathrm{C}-\mathrm{O}$ & 285.9 & 1.6 & 1.7 \\
\hline & $\mathrm{C}=\mathrm{O}, \mathrm{OC}=-\mathrm{O}$ & 288.9 & 2.0 & 1.5 \\
\hline \multirow[t]{5}{*}{ G109 } & $\mathrm{Al} 2 \mathrm{p} \mathrm{Al}-\mathrm{OA}-1$ & 73.6 & 1.3 & 27.2 \\
\hline & $\mathrm{C} 1 \mathrm{~s} \mathrm{C}=\mathrm{C}$ & 284.2 & 1.1 & 23.2 \\
\hline & $\mathrm{C}-\mathrm{C}, \mathrm{C}-\mathrm{H}$ & 284.8 & 1.2 & 5.4 \\
\hline & $\mathrm{C}-\mathrm{O}$ & 285.9 & 1.5 & 1.9 \\
\hline & $\mathrm{C}=\mathrm{O}, \mathrm{OC}=-\mathrm{O}$ & 288.9 & 1.9 & 1.4 \\
\hline \multirow[t]{5}{*}{ G145 } & $\mathrm{Al} 2 \mathrm{p} \mathrm{Al}-\mathrm{OA}-\mathrm{l}$ & 73.6 & 1.3 & 25.2 \\
\hline & $\mathrm{C} 1 \mathrm{~s} \mathrm{C}=\mathrm{C}$ & 284.3 & 1.0 & 27.1 \\
\hline & $\mathrm{C}-\mathrm{C}, \mathrm{C}-\mathrm{H}$ & 284.8 & 1.2 & 6.7 \\
\hline & $\mathrm{C}-\mathrm{O}$ & 285.9 & 1.6 & 2.7 \\
\hline & $\mathrm{C}=\mathrm{O}, \mathrm{OC}=-\mathrm{O}$ & 289.0 & 2.1 & 1.6 \\
\hline
\end{tabular}

for $\alpha-\mathrm{Al}_{2} \mathrm{O}_{3}$ and $2.1 \mathrm{~g} / \mathrm{cm}^{3}$ for graphene. The indentation tests $(200 \mathrm{~g}$, i.e. $1.96 \mathrm{~N}$, for $10 \mathrm{~s}$ in air at room temperature) were performed on the polished surface of the specimens by loading with a Vickers indenter (Mitutoyo HM 2000). The values reported are the average of at least 20 measurements. The transverse fracture strength $\left(\sigma_{\mathrm{f}}\right)$ was measured, parallel to the SPS pressing axis, by the three-point bending method (Material Testing Systems MTS $1 / \mathrm{M}$ ) on specimens about $1.8 \times 1.8 \times$ $18 \mathrm{~mm}^{3}$. The span between the two supporting pins is equal to $13 \mathrm{~mm}$. Cross-head speed was fixed at $0.1 \mathrm{~mm} / \mathrm{min}$. The toughness $\left(\mathrm{K}_{\mathrm{Ic}}\right)$ was measured, also parallel to the pressing axis, by the single-edged notched beam (SENB) method, on similar specimens notched with a diamond wire $0.17 \mathrm{~mm}$ in diameter. The notch depth/height ratio was verified to be slightly higher than 0.4 . A calibration factor [25] was used to calculate the SENB toughness from the experimental results. The values reported for $\sigma_{\mathrm{f}}$ and $\mathrm{K}_{\mathrm{Ic}}$ are the average of measurements conducted on seven or eight specimens. Note that the present experimental setup and calibration factor were used for earlier works on carbon nanotube$\mathrm{Al}_{2} \mathrm{O}_{3}$ composites $[26,27]$. The electrical conductivity was measured at room temperature with direct currents applied on $\left(1.8 \times 1.8 \times 5 \mathrm{~mm}^{3}\right)$ specimens, parallel to their length and perpendicular to their length, i.e. perpendicular and parallel to the SPS pressing axis, respectively. A silver paste was applied in order to connect the conducting electrodes. The current densities used were lower than $160 \mathrm{~mA} / \mathrm{cm}^{2}$ (Keithley 2400).

\section{Results and discussion}

\subsection{Powders}

The carbon content $\left(C_{n}-\right.$ Table 1$)$ in the powders was measured as
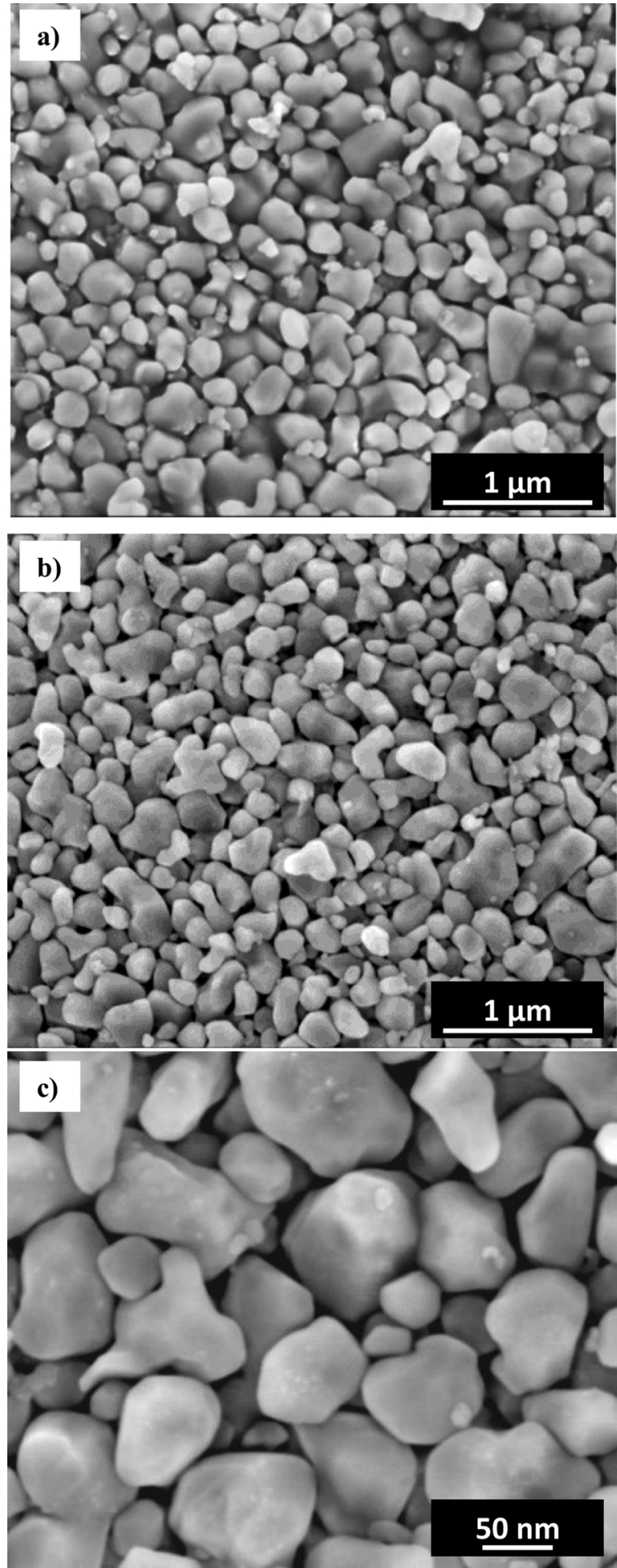

Fig. 3. FESEM images of the a) G74, b) and c) G145 powders.

equal to $0.13,0.39,0.58$ and 0.77 wt.\% (i.e. $0.24,0.74,1.09$ and 1.45 vol.\%) for the samples prepared using $1,4,5$ and $7 \mathrm{~L} / \mathrm{h}$ of $\mathrm{CH}_{4}$, respectively, in line with other works [23,24]. For the sake of brevity, the 

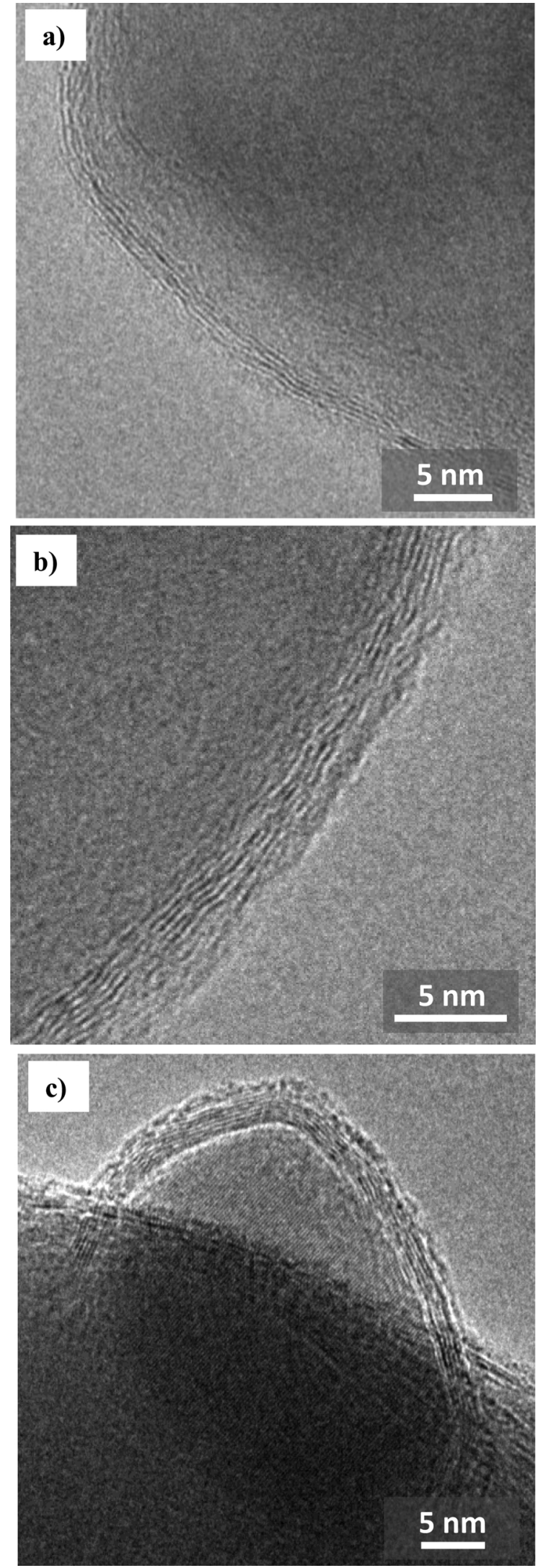

Fig. 4. High-magnification TEM images of the a) G74, b) G109 and c) G145 powders. powders will be denoted hereafter as G24, G74, G109 and G145, considering the carbon volume content. The XRD patterns (not shown) for all samples reveal only the peaks typical of $\alpha-\mathrm{Al}_{2} \mathrm{O}_{3}$ (corundum-type). No peak for any form of carbon is detected because of the very low content.

The Raman spectra (Fig. 1) show the carbon D, G and 2D bands ( $c a$. 1330,1590 and $2688 \mathrm{~cm}^{-1}$, respectively). For G24, a peak between the $\mathrm{D}$ and $\mathrm{G}$ bands is also observed ( $c a .1470 \mathrm{~cm}^{-1}$ ), which could correspond to the D" band that has been reported for samples containing disordered and/or amorphous carbon [28,29]. In addition to these peaks, fluorescence peaks of $\alpha-\mathrm{Al}_{2} \mathrm{O}_{3}$ are also detected for $\mathrm{G} 24$.

The Raman spectra (Fig. 1) are normalized with the $\mathrm{G}$ band at 100 $\%$. Despite some uncertainties, both the $\mathrm{I}_{\mathrm{D}} / \mathrm{I}_{\mathrm{G}}$ and the $\mathrm{I}_{2 \mathrm{D}} / \mathrm{I}_{\mathrm{G}}$ ratios (Table 1) decrease upon the increase in carbon content, which could traduce less disorder, i.e. less defects in the graphene layers and an increase in the number of layers, respectively [21]. Note however that the spectra for G74, G109 and G145 are not much different from each other. The 2D band position, shape and intensity are by and large in agreement with values commonly observed for FLG with 5-10 layers [30] but they all result from the contribution of several parameters including the number of graphene layers, the defects, the stacking order, the presence of strains within the stacking [27,31,32] and a more precise determination falls outside the scope of the present work.

The XPS spectra are presented in Fig. 2. $\alpha-\mathrm{Al}_{2} \mathrm{O}_{3}$ is used as a reference for $\mathrm{Al}$ environments. A graphene sample prepared elsewhere [23] was used as a reference for C environments. The semi-quantification of each chemical group contribution is reported in Table 2 . The range $280-294 \mathrm{eV}$ shows the response of carbon C1s. The different C1s contributions in the spectra are denoted by A symbols: A': $284.3 \mathrm{eV}$ for $\mathrm{C}=\mathrm{C}, \mathrm{A}$ ": $284.6 \mathrm{eV}$ for CC, CH, A"': $286.0 \mathrm{eV}$ for $\mathrm{CO}$ and A"'”: 287.0-290 eV for CO and OCO---==-. The C1s signals for G74, G109 and G145 are similar to each other and show an asymmetrical carbon at low binding energy (A'), highlighting the presence of graphene ( $\mathrm{sp}^{2}$ carbon hybridization). Hydrocarbon (A"), C-O (A"') and carbonyl/ester groups (A"') contributions are detected too. No aluminum carbides (C-Al, C1s contributions $<282 \mathrm{eV}$ ) and no aluminum oxycarbides (C-Al-O-C, C1s contributions $<282.5 \mathrm{eV}$ ) are detected. The $\mathrm{C} 1 \mathrm{~s}$ response for $\mathrm{G} 24$ is similar to that for the $\alpha-\mathrm{Al}_{2} \mathrm{O}_{3}$ reference, which could indicate very thin and/or incomplete layers, similar in signature to carbon from atmospheric pollution. The $70-78 \mathrm{eV}$ range describes the presence of aluminum Al2p. For all samples, only one chemical environment is found, $\mathrm{Al}-\mathrm{O}-\mathrm{Al}(73.6 \mathrm{eV}$, denoted $\mathrm{B}$ on the spectra), in comparison with the response of $\mathrm{Al} 2 \mathrm{p}$ for the $\alpha-\mathrm{Al}_{2} \mathrm{O}_{3}$ reference. This is by contrast to a study [21] where the formation of aluminum oxycarbide was reported. The latter samples were prepared at $1200{ }^{\circ} \mathrm{C}$, thus significantly higher than for the present study $\left(900{ }^{\circ} \mathrm{C}\right)$, and the formation mechanism of graphene were attributed to the carbothermal reduction occurring at the $\mathrm{Al}_{2} \mathrm{O}_{3}$ surface, with a chemical bonding between graphene and $\mathrm{Al}_{2} \mathrm{O}_{3}$ playing a significant role in the nucleation and growth of graphene. The present results do not point out the occurrence of the carbothermal reduction nor therefore to the necessity of such a mechanism for the deposition of carbon and the formation of FLG onto the $\alpha-\mathrm{Al}_{2} \mathrm{O}_{3}$ grains.

All powders were observed by FESEM and they look exactly the same. Typical FESEM images are shown for G74 (Fig. 3a) and G145 (Fig. 3b). They show $\alpha-\mathrm{Al}_{2} \mathrm{O}_{3}$ primary grains $100-500 \mathrm{~nm}$ in size. Graphene platelets or films were not observed on such images, probably due to their low thickness, even when using a higher-magnification as for G145 (Fig. 3c). TEM images of G74 (Fig. 4a), G109 (Fig. 4b) and 
Table 3

Characteristics and properties of the sintered specimens: carbon content $\left(\mathrm{C}_{\mathrm{v}}\right)$, relative density $(\rho), \mathrm{Al}_{2} \mathrm{O}_{3}$ matrix grain size (d), Vickers microhardness $\left(\mathrm{HV} \mathrm{V}_{0.2}\right)$, fracture strength $\left(\sigma_{\mathrm{f}}\right)$, SENB toughness $\left(\mathrm{K}_{\mathrm{Ic}}\right)$, electrical conductivity perpendicular $\left(\sigma_{\mathrm{e} \perp}\right)$ and parallel to the SPS pressing axis $\left(\sigma_{\mathrm{e} / /)}\right)$.

\begin{tabular}{|c|c|c|c|c|c|c|c|c|}
\hline $\begin{array}{l}\text { Specimen } \\
\text { or Ref. }\end{array}$ & $\begin{array}{l}\mathrm{C}_{\mathrm{v}} \\
\text { (vol.\%) }\end{array}$ & $\begin{array}{l}\rho \\
(\%)\end{array}$ & $\begin{array}{l}d \\
(\mu \mathrm{m})\end{array}$ & $\begin{array}{l}\mathrm{HV}_{0.2} \\
(\mathrm{GPa})\end{array}$ & $\begin{array}{l}\sigma_{\mathrm{f}} \\
(\mathrm{MPa})\end{array}$ & $\begin{array}{l}\mathrm{K}_{\mathrm{Ic}} \\
\left(\mathrm{MPa} \cdot \mathrm{m}^{1 / 2}\right)\end{array}$ & $\begin{array}{l}\sigma_{\mathrm{e} \perp} \\
\left(\mathrm{S} . \mathrm{cm}^{-1}\right)\end{array}$ & $\begin{array}{l}\sigma_{\mathrm{e} / /} \\
\left(\mathrm{S} . \mathrm{cm}^{-1}\right)\end{array}$ \\
\hline$\alpha-\mathrm{Al}_{2} \mathrm{O}_{3}$ & 0 & 99 & $0.89 \pm 0.28$ & $23.1 \pm 1.5$ & $435 \pm 125$ & $6.5 \pm 0.9$ & - & - \\
\hline $\mathrm{G} 24$ & 0.24 & 100 & $0.82 \pm 0.26$ & $23.1 \pm 1.5$ & $482 \pm 64$ & $6.9 \pm 0.5$ & - & - \\
\hline G74 & 0.74 & 99 & $0.51 \pm 0.17$ & $23.8 \pm 2.8$ & $551 \pm 47$ & $5.5 \pm 0.5$ & 0.68 & 0.27 \\
\hline G109 & 1.09 & 99 & $0.47 \pm 0.16$ & $22.1 \pm 4.0$ & $531 \pm 57$ & $5.8 \pm 0.5$ & 0.85 & 0.50 \\
\hline G145 & 1.45 & 99 & $0.46 \pm 0.15$ & $22.0 \pm 1.5$ & $516 \pm 37$ & $6.5 \pm 0.6$ & 1.84 & 0.71 \\
\hline$[6]$ & 3 & 100 & $<0.5$ & - & - & - & 0.03 & - \\
\hline [7] & 0.6 & - & $<0.5$ & - & - & - & 0.30 & - \\
\hline [7] & 2.35 & & $<0.5$ & - & - & - & 10.4 & - \\
\hline [8] & 0 & 99 & 4 & - & 320 & $3.5^{\mathrm{RC}}$ & - & - \\
\hline [8] & 0.30 & 99 & $<1$ & - & 610 & - & 0.001 & $7.10^{-5}$ \\
\hline [8] & 0.41 & 99 & $<1$ & - & 630 & $5.1^{\mathrm{RC}}$ & 0.067 & 0.013 \\
\hline [8] & 0.85 & 99 & $<1$ & - & 480 & - & 0.111 & 0.012 \\
\hline [9] & 0 & 100 & 2.39 & 18.4 & - & $2.9^{\mathrm{IND}}$ & - & - \\
\hline [9] & 5 & 99.4 & 1.27 & 15.1 & - & $2.6^{\mathrm{IND}}$ & - & - \\
\hline [9] & 7 & 98.7 & 1.31 & 13.1 & - & $2.8^{\mathrm{IND}}$ & - & - \\
\hline [9] & 9 & 99.2 & 1.31 & 11.8 & - & $3.0^{\mathrm{IND}}$ & 0.014 & 0.007 \\
\hline [9] & 15 & 98.5 & 1.33 & 9.8 & - & $3.2^{\mathrm{IND}}$ & 0.201 & 0.091 \\
\hline [10] & 0 & 100 & $3-4$ & 18.04 & 400 & $3.53^{\text {SEVNB }}$ & - & - \\
\hline [10] & 0.38 & 99.6 & $2-3$ & 17.66 & 523 & $4.49^{\text {SEVNB }}$ & - & - \\
\hline [10] & 0.76 & 99.9 & $2-3$ & 17.46 & 485 & 4.11 SEVNB & - & - \\
\hline [10] & 1.33 & 99.9 & $2-3$ & 16.32 & 464 & 3.94 SEVNB & - & - \\
\hline [12] & 0 & 99.6 & 2.4 & 18.8 & 348 & 3.11 IND & - & - \\
\hline [12] & 0.3 & 98.9 & - & 23.7 & 708 & $3.89^{\text {IND }}$ & - & - \\
\hline [12] & 0.6 & 97.4 & - & 21.5 & 597 & $3.58^{\text {IND }}$ & - & - \\
\hline [12] & 2 & 96.7 & 0.2 & 21.6 & 584 & 3.40 IND & - & - \\
\hline [13] & 0 & 99.8 & 0.53 & 22.9 & - & $2.9^{\mathrm{CN}} / 2.8^{\mathrm{IND}}$ & - & - \\
\hline [13] & 0.2 & 99.9 & - & 21.3 & - & $3.7^{\mathrm{CN}} / 3.5^{\mathrm{IND}}$ & - & - \\
\hline [13] & 0.8 & 99.9 & - & 21.6 & - & $3.7^{\mathrm{CN}} / 3.9^{\mathrm{IND}}$ & - & - \\
\hline [13] & 2 & 98.9 & 0.52 & 22.1 & - & $3.0^{\mathrm{CN}} / 2.9^{\mathrm{IND}}$ & - & - \\
\hline [15] & 0 & 100 & 1.5 & 17.2 & - & $3.3^{\mathrm{IND}}$ & - & - \\
\hline [15] & 0.47 & 99 & 1.2 & 17.9 & - & 4.1 IND & - & - \\
\hline [15] & 0.94 & 99 & 0.9 & 18.3 & - & $5.7^{\mathrm{IND}}$ & - & - \\
\hline [15] & 2.81 & 99 & 1.0 & 16.1 & - & $3.2^{\mathrm{IND}}$ & - & - \\
\hline [15] & 5.54 & 99 & 1.0 & 14.3 & - & $2.5^{\mathrm{IND}}$ & - & - \\
\hline [16] & 0 & 99.5 & 1.17 & 22.3 & - & $3.2^{\mathrm{CN}}$ & - & - \\
\hline [16] & 0.8 & 97.4 & 1.23 & 21.9 & - & $4.3^{\mathrm{CN}}$ & - & - \\
\hline [17] & 0 & - & - & - & 290 & $3.9^{\mathrm{IND}}$ & - & - \\
\hline [17] & 0.25 & - & - & - & 384 & $5.7^{\mathrm{IND}}$ & - & - \\
\hline [17] & 0.75 & - & - & - & 461 & $6.2^{\mathrm{IND}}$ & - & - \\
\hline [17] & 1 & - & - & - & 406 & $5.5^{\mathrm{IND}}$ & - & - \\
\hline [24] & 0 & 99.9 & 2.5 & 21.9 & 500 & $2.8^{\mathrm{IND}}$ & $<10^{-12}$ & - \\
\hline [24] & 0.17 & 99.9 & 0.98 & 24.5 & 410 & 3.1 IND & $<10^{-12}$ & - \\
\hline [24] & 1.03 & 99.8 & 0.35 & 21.3 & 400 & $3.6^{\mathrm{IND}}$ & 0.02 & - \\
\hline [24] & 1.74 & 98.2 & 0.27 & 20.1 & 310 & $3.3^{\mathrm{IND}}$ & 2.67 & - \\
\hline
\end{tabular}

CN Chevron Notch; IND: Indentation; RC: R-curve; SEVNB: Single Edge V-notched beam.

G145 (Fig. 4c) reveal that for all three powders, the surface of the $\alpha$ $\mathrm{Al}_{2} \mathrm{O}_{3}$ grains is covered by a few (4-8) graphene layers. Disorganized carbon was not evidenced on TEM images but its presence at a very low amount cannot be ruled out. These observations are in agreement with results reported for other oxide powders [22-24].

\subsection{Dense samples}

The sintered specimens are denoted like the corresponding powders. The relative density of all specimens is equal to or above $99 \pm 1 \%$ (Table 3). The Raman spectra (Fig. 5 and Table 3) do not show much change compared to those of the respective powders (Fig. 1), which could indicate no or little damage to the FLG upon sintering by SPS.

The fracture surfaces of the samples (Fig. 6) were observed by
FESEM. The average $\alpha-\mathrm{Al}_{2} \mathrm{O}_{3}$ grain size (d - Table 3), determined from such images, is equal to $0.89 \mu \mathrm{m}$ for $\alpha-\mathrm{Al}_{2} \mathrm{O}_{3}$ (Fig. 6a). This relatively grain low size (i.e. submicron) for a dense $\alpha-\mathrm{Al}_{2} \mathrm{O}_{3}$ sample is achieved because the SPS process allows densification at relatively low temperatures, thus limiting grain growth [33]. The average $\alpha-\mathrm{Al}_{2} \mathrm{O}_{3}$ matrix grain size for G24 (image not shown) is slightly lower $(0.82 \mu \mathrm{m})$ and is about twice lower for the specimens containing more carbon: $0.51 \mu \mathrm{m}$ for G74 (Fig. 6c and d), $0.47 \mu \mathrm{m}$ for G109 (Fig. 6e and f) and $0.46 \mu \mathrm{m}$ for G145 (Fig. $6 \mathrm{~g}$ and $\mathrm{h}$ ). This could indicate that the graphene layers around the $\alpha-\mathrm{Al}_{2} \mathrm{O}_{3}$ grains hamper the motion of grain boundaries during sintering and thus limit matrix grain growth, in line with other works $[23,24]$. This effect is however much less pronounced than for the FLG/MgO samples where there was a 15-fold difference in $\mathrm{MgO}$ grain size [23]. Note that the low magnification FESEM images of all 


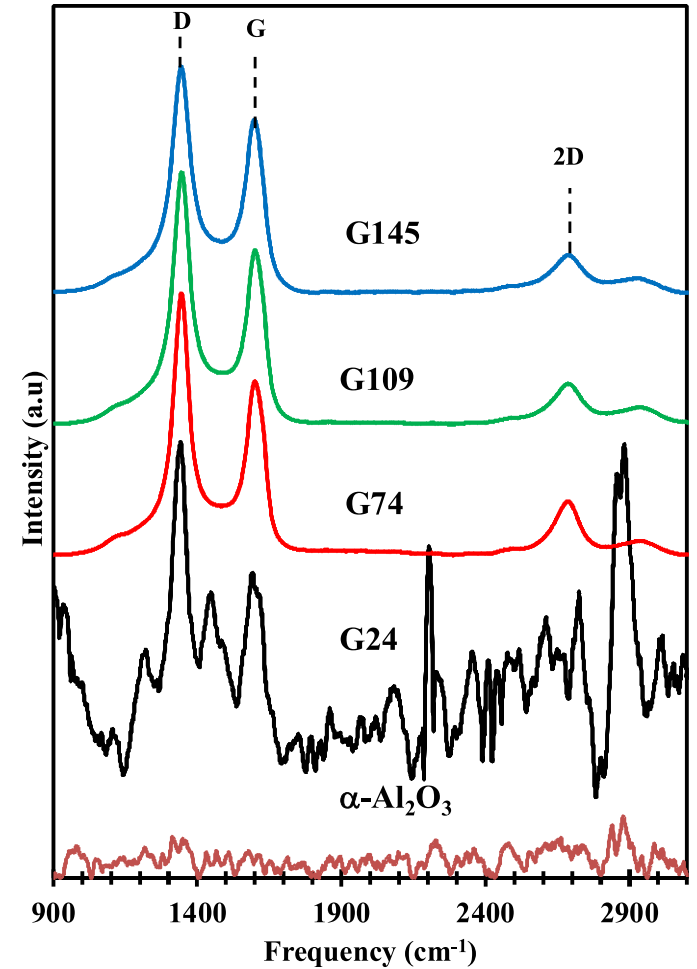

Fig. 5. Raman spectra of the dense $\alpha-\mathrm{Al}_{2} \mathrm{O}_{3}$ and $\mathrm{FLG} / \mathrm{Al}_{2} \mathrm{O}_{3}$ samples (G24, G74, G109 and G145). The spectra of G74, G109 and G145 are normalized with the G band at $100 \%$.The dashed lines are guides to the eye.

three composites (Fig. 6c, e and g) reveal a very uniform matrix grain size, which reflects the very homogeneous dispersion of graphene at the matrix grain boundaries. This is a direct consequence of the very homogeneous dispersion of graphene around the grains in the powder, which is a key feature of the one-step synthesis route. Moreover, these images reveal a transgranular-intergranular mixed fracture mode for $\alpha$ $\mathrm{Al}_{2} \mathrm{O}_{3}$ (Fig. 6a) and an intergranular fracture mode for composites (Fig. 6c, e and g). For all composites, there are some areas where the partly debonded FLG film is observed in a transverse orientation (arrowed in Fig. 6d, f and h). Note that the Pt-coating a few nanometers thick used for the preparation of SEM samples results in an overestimation of the FLG thickness. There is no observed particular orientation of the FLG with respect to the pressing axis, as also noted elsewhere $[23,24]$ but unlike in composites prepared by mixing GNP or GNS with the matrix powder or precursor, where the GNP or GNS are mostly aligned in the plane perpendicular to the pressing direction $[8,9,13,16]$.

TEM observations of the G145 specimen (Fig. 7a) show $\alpha-\mathrm{Al}_{2} \mathrm{O}_{3}$ grains about $200 \mathrm{~nm}$ in size separated by sharp grain boundaries. HRTEM images of the grain boundaries (Fig. 7b-d) reveal fringes corresponding to fairly well-organized FLG about $2-5 \mathrm{~nm}$ thick. The number of graphene layers at the grain boundaries is thus ranging from 6 to 12, i.e. roughly twice the number of graphene layers covering the $\alpha-\mathrm{Al}_{2} \mathrm{O}_{3}$ grains in the corresponding powder (Fig. 2c). These observations confirm the above Raman spectroscopy results revealing no or little damage to the FLG upon sintering by SPS.

The electrical conductivity for the $\alpha-\mathrm{Al}_{2} \mathrm{O}_{3}$ and $\mathrm{G} 24$ sample is not measurable, either in the direction perpendicular $\left(\sigma_{\mathrm{e} \perp}-\right.$ Table 3$)$ or parallel to the SPS pressing axis ( $\sigma_{\mathrm{e} / /}-$ Table 3). For G74, G109 and G145, both $\sigma_{\mathrm{e} \perp}$ and $\sigma_{\mathrm{e} / /}$ increase upon the increase in carbon content, with $\sigma_{e \perp}$ about 1.7-2.6 times higher than $\sigma_{e / /}$ (Table 3). This could indicate that although not observed on the FESEM images, there is some degree of anisotropy induced by the uniaxial pressing during SPS. The maximum value measured $\left(\sigma_{\mathrm{e} \perp}=1.84 \mathrm{~S} \mathrm{~cm}-1\right.$ for G145) is significantly higher than some values reported elsewhere for $\mathrm{FLG} / \mathrm{Al}_{2} \mathrm{O}_{3}$ samples, even for higher carbon contents $[8,9]$. They are in line with some others, $10.4 \mathrm{~S} . \mathrm{cm}^{-1}$ for $2.35 \mathrm{vol} \%$ of carbon dispersed as very thin FLG [7] and $2.67 \mathrm{~S} . \mathrm{cm}^{-1}$ for $1.74 \mathrm{vol} . \%$ of carbon prepared by the CVD route [24] (Table 3). This could reflect the high quality of the FLG film in the present samples and its continuous nature over very long distances, in line with results reported for carbon nanotube - oxide composites [34,35], where the carbon nanotubes are significantly longer than the matrix grains. This is by contrast to samples where there are a great many of individual FLG platelets with submicron lateral dimensions along the conducting path, therefore contributing more to contact resistance. The change between G24 (conductivity not measurable) and G74 $\left(\sigma_{\mathrm{e} \perp}=0.68 \mathrm{~S} \mathrm{~cm}^{-1}\right.$ and $\left.\sigma_{\mathrm{e} / /}=0.27 \mathrm{~S} \mathrm{~cm}^{-1}\right)$ could indicate that the electrical percolation threshold is between 0.24 and 0.74 vol.\%. This is slightly lower than for $\mathrm{FLG} / \mathrm{Al}_{2} \mathrm{O}_{3}$ samples [24] with a similar microstructure but in line with data reported for FLG/MgO composites [23], other $\mathrm{GNS} / \mathrm{Al}_{2} \mathrm{O}_{3}$ samples $[7,8]$ and carbon nanotube oxide composites [31]. However, it is markedly lower than for GNS/ $\mathrm{Al}_{2} \mathrm{O}_{3}$ samples with thicker GNS (about 3 vol.\% [6] and 7 vol.\% [9]). Detailed discussions have been reported on the topic of the percolation threshold [7-9] but here further work is warranted in order to get a better determination of the precise nature of the percolating system.

The Vickers microhardness $\left(\mathrm{HV}_{0.2}-\right.$ Table 3$)$ is in the range 22.0-23.8 GPa, in line with [24], and is similar for all samples despite the admittedly decreasing size of the matrix grains upon the increase in carbon content. These values are however typical for $\alpha-\mathrm{Al}_{2} \mathrm{O}_{3}$ in the $0.3-1.2 \mu \mathrm{m}$ size range [32]. Other authors $[10,11,13,15,16]$ have reported that the Vickers microhardness decreases slightly upon the increase in carbon content, when there is also only a minor decrease in the matrix grain size. The transverse fracture strength $\left(\sigma_{\mathrm{f}}\right.$ - Table 3 ) for $\alpha-\mathrm{Al}_{2} \mathrm{O}_{3}$ is equal to $435 \mathrm{MPa}$ and is slightly higher for the $\mathrm{FLG} / \mathrm{Al}_{2} \mathrm{O}_{3}$ samples, in the range $482-551 \mathrm{MPa}$, by contrast to what has been reported by other authors [24]. The reinforcement achieved appears to be lower than what has been reported earlier $[8,10,11,17]$, but note that the present $\alpha-\mathrm{Al}_{2} \mathrm{O}_{3}$ is also stronger. In agreement with other results, the maximum reinforcement is obtained for very low carbon contents and a further increase is detrimental. The fracture toughness $\left(\mathrm{K}_{\mathrm{Ic}}\right.$ - Table 3) for $\alpha-\mathrm{Al}_{2} \mathrm{O}_{3}$ is equal to $6.5 \mathrm{MPa} \cdot \mathrm{m}^{1 / 2}$, a relatively high value. It is not markedly different for the composites, between 5.5 and 6.9 MPa.m ${ }^{1 / 2}$. Yao et al. [36] have shown that the fracture toughness for fine grained $(0.3-3 \mu \mathrm{m}) \alpha-\mathrm{Al}_{2} \mathrm{O}_{3}$ is not grain-size dependant. Other authors have reported no toughening [9] or a moderate one $[8,10,13,15-17,24]$ but their reported value for $\alpha-\mathrm{Al}_{2} \mathrm{O}_{3}$ is lower than the present one. In addition, it is worth noting that many different methods are used to evaluate the toughness, such as Chevron Notch, Indentation, R-curve, Single Edge Notched Beam and Single Edge VNotched Beam (Table 3). This has been found [37] to be a source for conflicting results on toughening in the case of carbon nanotubeceramic composites. Therefore, it is clearly a field deserving more work, round-robin tests coming to mind.

Vickers indentations were performed on the surface of G145 using a deliberately high load $(2 \mathrm{~kg})$ in order to produce cracks, which were observed by FESEM (Fig. 8).

The path of the cracks is intergranular and quite tortuous, revealing 

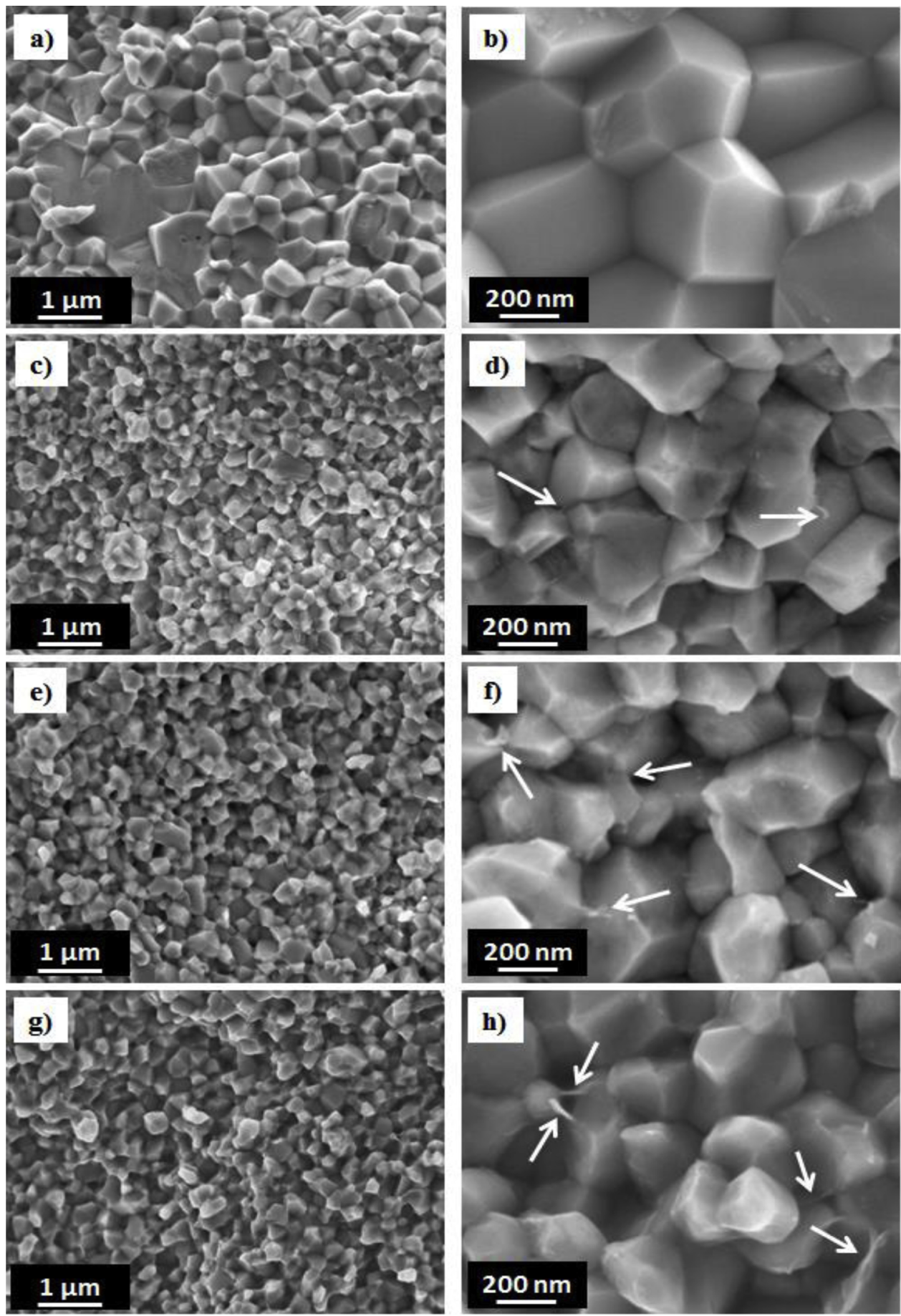

Fig. 6. FESEM images of the fracture surface of the specimens prepared by SPS a) and b) $\alpha-\mathrm{Al}_{2} \mathrm{O}_{3}$, c) and d) G74, e) and f) G109, g) and h) G145. Arrows point to the FLG observed in a transverse orientation. 

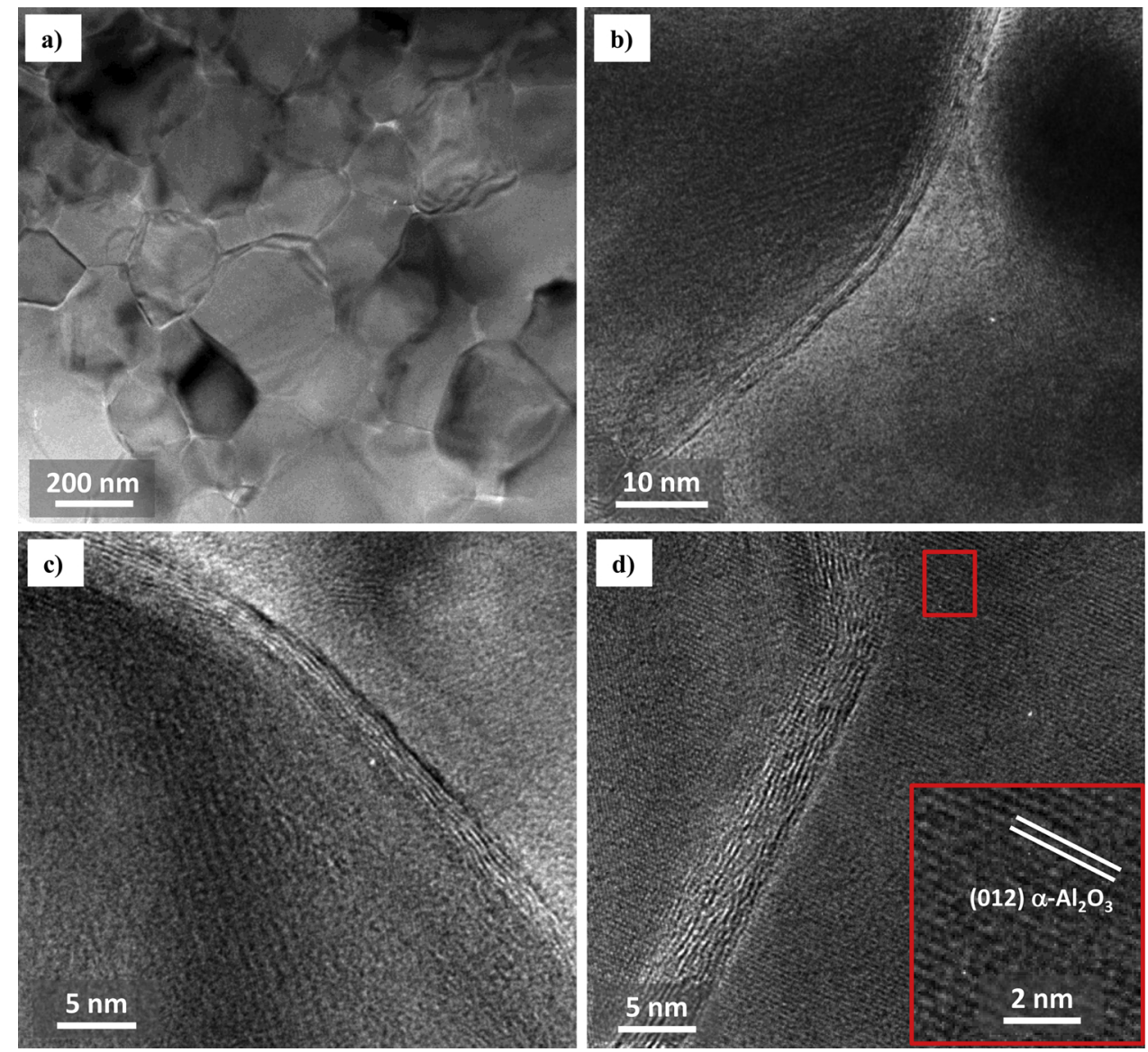

Fig. 7. TEM image a) of a thin foil of the G145 specimen sintered by SPS and HRTEM images b), c) and d) of the grain boundaries.

crack-deflection (Fig. 8a and b). Crack-bridging by the FLG film is observed. Some images also show the debonding of the FLG film as it bridges two grains (arrowed in Fig. 8c). The large surface area of graphene in contact with the $\alpha-\mathrm{Al}_{2} \mathrm{O}_{3}$ grain causes a large adhering surface, improving the anchoring to the sides of the crack and hampering crack propagation [8]. Other authors [8,10,14-16] have also reported crackbranching, crack-deflection and crack-bridging as toughening mechanisms in the case of discrete graphene particles (GNS, GNP, ...) dispersed into $\alpha-\mathrm{Al}_{2} \mathrm{O}_{3}$. A toughening mechanism involving a continuous wall of graphene along $\mathrm{Si}_{3} \mathrm{~N}_{4}$ grain boundaries has been reported [38]. The graphene layers wrapping the $\mathrm{Si}_{3} \mathrm{~N}_{4}$ grains anchor themselves around them and show a resistance to pullout. These authors also proposed that the continuous wall of graphene along the grain boundaries forces the cracks to propagate in not just two but in three dimensions in order to continue to propagate through the material. The similarity with the present microstructure could make it a possibility, although admittedly no macroscopic toughening is observed for the present samples.

\section{Conclusions}

In conclusion, we have reported the preparation of graphene $/ \mathrm{Al}_{2} \mathrm{O}_{3}$ composite powders in a simple, one-step, route involving the chemical vapor deposition of carbon onto the $\alpha-\mathrm{Al}_{2} \mathrm{O}_{3}$ powder grains. This obviates both lengthy mixing steps and the risk of damaging any preexisting graphite or graphene platelets. It is shown that carbon is deposited in the form of pristine few-layered-graphene films (about 4-8 layers) wrapping the $\alpha-\mathrm{Al}_{2} \mathrm{O}_{3}$ grains. The samples are consolidated to $99 \%$ by SPS. It is shown that a FLG film is located along the grain boundaries of the submicron $\alpha-\mathrm{Al}_{2} \mathrm{O}_{3}$, as opposed to be dispersed as discrete particles. The so-obtained composites are moderately stronger and similarly tough and hard than the present pure submicron $\alpha-\mathrm{Al}_{2} \mathrm{O}_{3}$. Crack-deflection and crack-bridging have been observed and it is proposed that the adhesion of a large surface area of graphene in contact with the $\alpha-\mathrm{Al}_{2} \mathrm{O}_{3}$ grain significantly improves the anchoring to the sides of the crack and hampers crack propagation. Moreover, the samples are electrically conducting with a percolation threshold below 0.74 vol.\%. The study reveals that the conductivity values achieved $\left(1.84 \mathrm{~S} \mathrm{~cm}^{-1}\right.$ for $1.45 \mathrm{vol} . \%$ of carbon) reflect the high structural quality of the thin FLG film in the present samples and its continuous nature over very long distances. The proposed synthesis method for the direct preparation of FLG-containing powders is simple to perform, does not involve the manipulation of nanocarbons and is dependent on mature industrial technology and therefore prone to up-scaling. Interestingly, it can be used on almost any powder bed by fine-tuning the experimental conditions, such as using different carbon sources. 

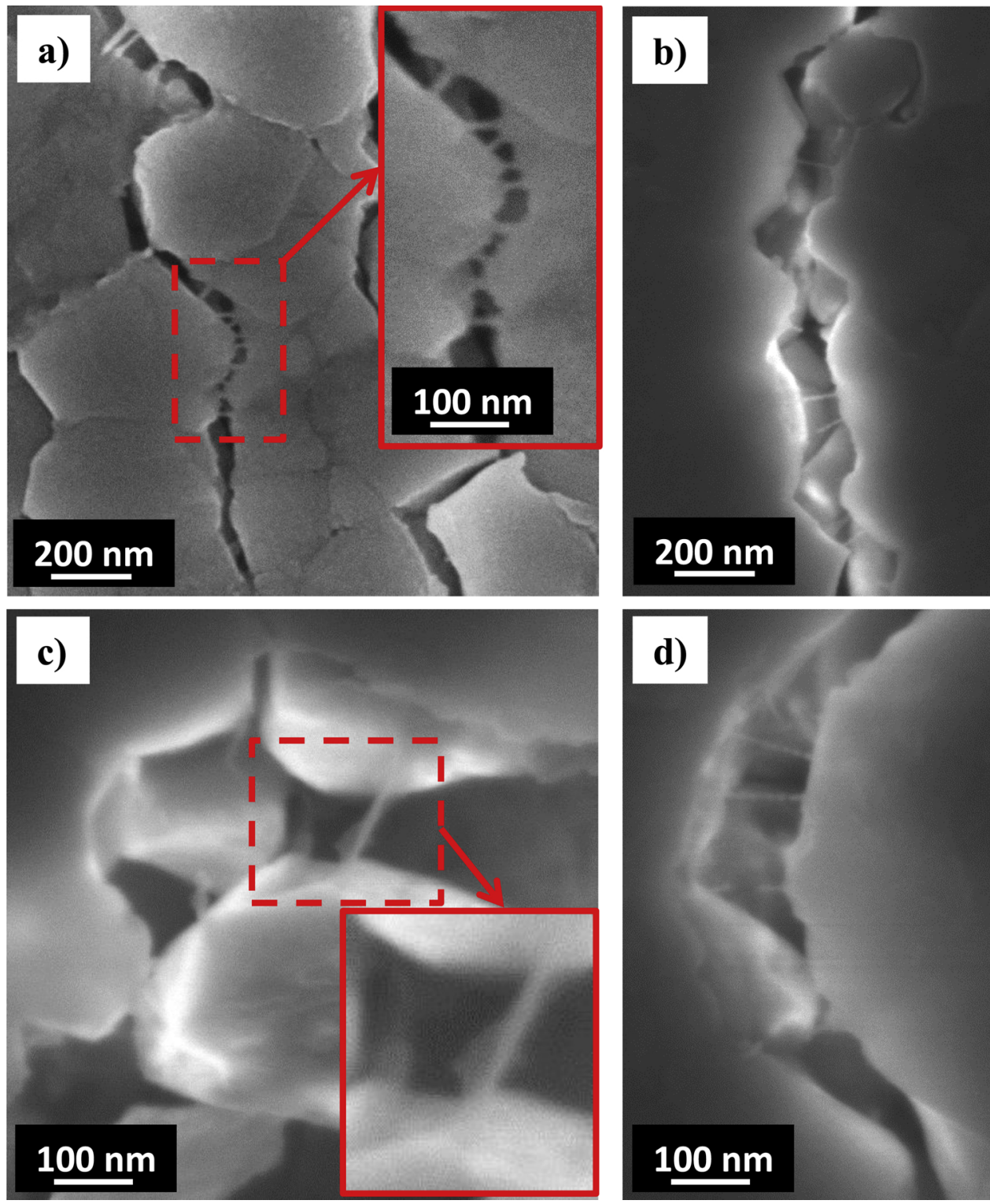

Fig. 8. FESEM images showing sample G145 with cracks made on purpose, revealing a) and b) crack-deflection a), b), c) and d) crack-bridging and c) the debonding of the FLG film bridging two grains.

\section{Declaration of Competing Interest}

None.

\section{Acknowledgments}

The authors thank S. Huet for preliminary works on sample synthesis and characterization. Electron microscopy was performed at "Centre de microcaractérisation Raimond Castaing - UMS 3623" (Toulouse) and the authors thank L. Weingarten for help with the TEM observations. The SPS was performed at the Plateforme Nationale CNRS de Frittage-Flash ( $\mathrm{PNF}^{2}$, Toulouse).

\section{References}

[1] H. Porwal, S. Grasso, M.J. Reece, Review of graphene-ceramic matrix composites, Adv. Appl. Ceram. 112 (2013) 443-454, https://doi.org/10.1179/ 174367613 X13764308970581.

[2] A. Nieto, A. Bisht, D. Lahiri, C. Zhang A. Agarwal, Graphene reinforced metal and ceramic matrix composites: a review, Int. Mater. Rev. 62 (2017) 241-302, https:// doi.org/10.1080/09506608.2016.1219481.
[3] P. Miranzo, M. Belmonte, M.I. Osendi, From bulk to cellular structures: a review on ceramic/graphene filler composites, J. Eur. Ceram. Soc. 37 (2017) 3649-3672, https://doi.org/10.1016/j.jeurceramsoc. 2017.03.016.

[4] K. Markandan, J.K. Chin, M.T.T. Tan, Recent progress in graphene based ceramic composites: a review, J. Mater. Res. 32 (2017) 84-106, https://doi.org/10.1557/ jmr.2016.390.

[5] P. Rutkowski, P. Klimczyk, L. Jaworska, L. Stobierski, A. Dubiel, Thermal properties of pressure sintered alumina-graphene composites, J. Therm. Anal. Calorim. 122 (2015) 105-114, https://doi.org/10.1007/s10973-015-4694-x.

[6] Y. Fan, L. Wang, J. Li, J. Li, S. Sun, F. Chen, L. Chen, W. Jiang, Preparation and electrical properties of graphene nanosheet $/ \mathrm{Al}_{2} \mathrm{O}_{3}$ composites, Carbon 48 (2010) 1743-1749, https://doi.org/10.1016/j.carbon.2010.01.017.

[7] Y. Fan, W. Jiang, A. Kawasaki, Highly Conductive few-layer graphene/ $\mathrm{Al}_{2} \mathrm{O}_{3}$ nanocomposites with tunable charge carrier type, Adv. Funct. Mater. 22 (2012) 3882-3889, https://doi.org/10.1002/adfm.201200632.

[8] A. Centeno, V.G. Rocha, B. Alonso, A. Fernández, C.F. Gutierrez-Gonzalez, R. Torrecillas, A. Zurutuza, Graphene for tough and electroconductive alumina ceramics, J. Eur. Ceram. Soc. 33 (2013) 3201-3210, https://doi.org/10.1016/j. jeurceramsoc.2013.07.007.

[9] Y. Celik, A. Celik, E. Flahaut, E. Suvaci, Anisotropic mechanical and functional properties of graphene-based alumina matrix nanocomposites, J. Eur. Ceram. Soc. 36 (2016) 2075-2086, https://doi.org/10.1016/j.jeurceramsoc.2016.02.032.

[10] J. Liu J, H. Yan, K. Jiang, Mechanical properties of graphene platelet-reinforced alumina ceramic composites, Ceram. Int. 39 (2013) 6215-6221, https://doi.org/10. 1016/j.ceramint.2013.01.041.

[11] Y. Fan, M. Estili, G. Igarashi, W. Jiang, A. Kawasaki, The effect of homogeneously 
dispersed few-layer graphene on microstructure and mechanical properties of $\mathrm{Al}_{2} \mathrm{O}_{3}$ nanocomposites, J. Eur. Ceram. Soc. 34 (2014) 443-451, https://doi.org/10.1016/ j.jeurceramsoc.2013.08.035.

[12] X. Liu, Y. Fan, J.-L. Li, L.-J. Wang, W. Jiang, Preparation and mechanical properties of graphene nanosheet reinforced alumina composites, Adv. Eng. Mater. 17 (2015) 28-35, https://doi.org/10.1002/adem.201400231.

[13] H. Porwal, P. Tatarko, S. Grasso, J. Khaliq, I. Dlouhý, M.J. Reece, Graphene re inforced alumina nano-composites, Carbon 64 (2013) 359-369, https://doi.org/10. 1016/j.carbon.2013.07.086.

[14] H. Porwal, R. Saggar, P. Tatarko, S. Grasso, T. Saunders, I. Dlouhý, M.J. Reece, Effect of lateral size of graphene nano-sheets on the mechanical properties and machinability of alumina nano-composites, Ceram. Int. 42 (2016) 7533-7542, https://doi.org/10.1016/j.ceramint.2016.01.160.

[15] I. Ahmad, M. Islam, H.S. Abdo, T. Subhani, K.A. Khalil, A.A. Almajid, B. Yazdani, Y. Zhu, Toughening mechanisms and mechanical properties of graphene nanosheetreinforced alumina, Mater. Des. 88 (2015) 1234-1243, https://doi.org/10.1016/j. matdes.2015.09.125.

[16] X. Meng, C. Xu, G. Xiao, M. Yi, Y. Zhang, Microstructure and anisotropy of me chanical properties of graphene nanoplate toughened $\mathrm{Al}_{2} \mathrm{O}_{3}$-based ceramic composites, Ceram. Int. 42 (2016) 16090-16095, https://doi.org/10.1016/j.ceramint. 2016.07.121.

[17] S.N. Alam, N. Sharma, B.C. Ray, S. Yadav, K. Biswas, Effect of graphite nanoplatelets on the mechanical properties of alumina based composites, Ceram. Int. 43 (2017) 11376-11389 doi :0.1016/j.ceramint.2017.05.345.

[18] W.S. Hummers, R.E. Offeman, Preparation of graphitic oxide, J. Am. Chem. Soc. 80 (1958), https://doi.org/10.1021/ja01539a017 1339-1339.

[19] M. Yi, Z. Shen, A review on mechanical exfoliation for the scalable production of graphene, J. Mater. Chem. A 3 (2015) 11700-11715, https://doi.org/10.1039/ C5TA00252D

[20] M. Zhou, T. Lin, F. Huang, Y. Zhong, Z. Wang, Y. Tang, H. Bi, D. Wan, J. Lin, Highly conductive porous graphene/ceramic composites for heat transfer and thermal energy storage, Adv. Funct. Mater. 23 (2013) 2263-2269, https://doi.org/10.1002/ adfm.201202638 2013.

[21] M. Zhou, H. Bi, T. Lin, X. Lu, D. Wan, F. Huang, J. Lin, Heat transport enhancement of thermal energy storage material using graphene/ceramic composites, Carbon 75 (2014) 314-321, https://doi.org/10.1016/j.carbon.2014.04.009.

[22] M.H. Rümmeli, C. Kramberger, A. Grüneis, P. Ayala, T. Gemming, B. Büchner, T. Pichler, On the graphitization nature of oxides for the formation of carbon nanostructures, Chem. Mater. 19 (2007) 4105-4107, https://doi.org/10.1021/ cm0712220.

[23] A. Weibel, D. Mesguich, G. Chevallier, E. Flahaut, Ch. Laurent, Fast and easy preparation of few-layered-graphene/magnesia powders for strong, hard and electrically conducting composites, Carbon 136 (2018) 270-279, https://doi.org/10. 1016/j.carbon.2018.04.085.

[24] M. Hrubovčáková, E. Múdra, R. Bureš, A. Kovalčíková, R. Sedlák, V. Girman, P. Hvizdoš, Microstructure, fracture behaviour and mechanical properties of conductive alumina based composites manufactured by SPS from graphenated $\mathrm{Al}_{2} \mathrm{O}_{3}$ powders, J. Eur. Ceram. Soc. (2020), https://doi.org/10.1016/j.jeurceramsoc.2020. 03.072 In press, journal pre-proof, available online 9 April.
[25] W.F. Brown, J.E. Srawley, Plane Strain Crack Toughness Testing of High Strength Metallic Materials, American Society For Testing And Materials, Philadelphia, PA (USA), 1966.

[26] E. Flahaut, A. Peigney, C. Laurent, C. Marlière, F. Chastel, A. Rousset, Carbon nanotube-metal-oxide nanocomposites: microstructure, electrical conductivity and mechanical properties, Acta Mater. 48 (2000) 3803-3812, https://doi.org/10. 1016/S1359-6454(00)00147-6.

[27] A. Kasperski, A. Weibel, C. Estournès, C. Laurent, A. Peigney, Multi-walled carbon nanotube-Al2O3 composites: covalent or non-covalent functionalization for mechanical reinforcement, Scripta Mater. 75 (2014) 46-49, https://doi.org/10.1016/ j.scriptamat.2013.11.015.

[28] A. Sadezkya, H. Muckenhuber, H. Grothe, R. Niessner, U. Pöschl, Raman microspectroscopy of soot and related carbonaceous materials: spectral analysis and structural information, Carbon 43 (2005) 1731-1742, https://doi.org/10.1016/j carbon.2005.02.018.

[29] T. Jawhari, A. Roid, J. Casado, Raman spectroscopic characterization of some commercially available carbon black materials, Carbon 33 (1995) 1561-1565, https://doi.org/10.1016/0008-6223(95)00117-V.

[30] A.C. Ferrari, J.C. Meyer, V. Scardaci, C. Casiraghi, M. Lazzeri, F. Mauri, S. Piscanec, D. Jiang, K.S. Novoselov, S. Roth, A.K. Geim, Raman spectrum of graphene and graphene layers, Phys. Rev. Lett. 97 (2006) 187401, , https://doi.org/10.1103/ PhysRevLett.97.187401.

[31] G. Tsoukleri, J. Parthenios, K. Papagelis, R. Jalil, A.C. Ferrari, A.K. Geim, K.S. Novoselov, C. Galiotis, Subjecting a graphene monolayer to tension and compression, Small 5 (2009) 2397-2402, https://doi.org/10.1002/smll.200900802.

[32] T.A. Nguyen, J.-U. Lee, De Yoon, H. Cheong, Excitation energy dependent Raman signatures of ABA- and ABC-stacked few-layer graphene, Sci. Rep. 4 (2014), https:// doi.org/10.1038/srep04630 4630-1 - 4630-4635.

[33] J. Gurt Santanach, A. Weibel, C. Estournès, Q. Yang, Ch. Laurent, A. Peigney, Spark plasma sintering of alumina: study of parameters, formal sintering analysis and hypotheses on the mechanism(s) involved in densification and grain growth, Acta Mater. 59 (2011) 1400-1408, https://doi.org/10.1016/j.actamat.2010.11.002.

[34] S. Rul, F. Lefèvre-Schlick, E. Capria, C. Laurent, A. Peigney, Percolation of singlewalled carbon nanotubes in ceramic matrix nanocomposites, Acta Mater. 52 (2004) 1061-1067, https://doi.org/10.1016/j.actamat.2003.10.038.

[35] A. Kasperski, A. Weibel, C. Estournès, Ch. Laurent, A. Peigney, Preparation-microstructure-property relationships in double-walled carbon nanotubes/alumina composites, Carbon 53 (2013) 62-72, https://doi.org/10.1016/j.carbon.2012.10. 030 .

[36] W. Yao, J. Liu, T.B. Holland, L. Huang, Y. Xiong, J.M. Schoenung, A.K. Mukherjee, Grain size dependence of fracture toughness for fine grained alumina, Scripta Mater. 65 (2011) 143-146, https://doi.org/10.1016/j.scriptamat.2011.03.032.

[37] X. Wang, N.P. Padture, H. Tanaka, Contact-damage-resistant ceramic/singlewall carbon nanotubes and ceramic/graphite composites, Nature Mater. 3 (2004) 539-544, https://doi.org/10.1038/nmat1161.

[38] L.S. Walker, V.R. Marotto, M.A. Rafiee, N. Koratkar, E.L. Corral, Toughening in graphene ceramic composites, ACS Nano 5 (2011) 3182-3190, https://doi.org/10. 1021/nn200319d. 